\title{
Measurement and Modeling of Carbon Balance of the Apple Tree
}

\author{
A.N. Lakso \\ Department of Horticultural Sciences, New York State Agricultural Experiment Station, Geneva, NY 14456
}

\section{J.N. Wünsche and J.W. Palmer}

HortResearch, Riwaka Research Station, Motueka, New Zealand

L. Corelli Grappadelli

Dipartimento di Colture Arboree, Universitá di Bologna, Bologna, Italy

\begin{abstract}
Apple (Malus $\times$ domestica Borkh.) trees can produce very large crops under optimal conditions. In New Zealand, record yields approaching 120 to $140 \mathrm{t} \cdot \mathrm{ha}^{-1}$ fresh weight $\left(\approx 18-20 \mathrm{t} \cdot \mathrm{ha}^{-1}\right.$ dry weight) have been sustained over several years (D.S. Tustin, personal communication). The high yields in New Zealand have been attributed to relatively cool but sunny growing conditions and a long postharvest season (Wünsche and Palmer, 1997). Thus, for $\mathrm{a}_{3}$ crop, apple has high potential productivity.

In a classic study, Monteith (1977) elucidated that dry-matter productivity of crops, including apple, is essentially a linear function of total radiant energy interception over the season. The slope of the relationship (i.e., the conversion of absorbed radiation to dry matter)
\end{abstract}

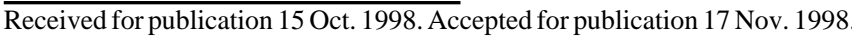
The cost of publishing this paper was defrayed in part by the payment of page charges. Under postal regulations, this paper therefore must be hereby marked advertisement solely to indicate this fact. is called the "dry matter : radiation quotient" (Russell et al., 1989). This relationship has been further verified for apple (Palmer, 1988, 1989). Many reports indicate that yields of apple orchards are correlated with light interception, although high light interception does not guarantee high yields because of detrimental effects of excessive shade within the canopies (see reviews by Jackson, 1980; Lakso, 1994; Palmer, 1989; and Wagenmakers, 1991, 1996). We will review the components of light interception, the conversion to dry matter, and the partitioning of dry matter to fruit that lead to the high productivity of apple.

\section{COMPONENTS OF PRODUCTIVITY}

\section{Carbon reserves}

Perennial crops like apple require the storage of carbon and other nutrients to support initial growth in the spring. Studies of nonstructural carbohydrate levels per unit of tissue weight over the season in apple 
have shown the general seasonal pattern of a rapid decline of reserves from dormant-season levels beginning when initial spring growth occurs (Hennerty and Forshey, 1971; Priestley, 1960, 1963). By bloom or shortly thereafter, the reserves reach a minimum, after which they gradually increase over the season, peaking at leaf fall. Since the reserves per unit tissue weight normally increase after bloom, carbon reserves apparently do not generally support shoot or fruit growth. Studies underway, however, are evaluating the potential for utilization of reserves for fruit growth when sink/source balance is changed by severe treatments such as defoliation (P. Minchin and J. Wünsche, personal communication).

Although critical for early growth, the total contribution of carbon reserves to seasonal carbon balance of the apple tree is difficult to evaluate. The fraction of reserves (sugars, starch, and hemicellulose) normally utilized in the spring appears to be about one-third of the total extractable carbohydrates. However, trees placed in total darkness utilized no more than about half of their extractable insoluble carbohydrates even though the soluble sugars were fully utilized (Priestley, 1963). This indicates that all chemically extractable reserves are not physiologically "available." Unfortunately, Priestley's is the only study we are aware of on this important point.

Additionally, the total pool of reserves (total tissue weight $\times$ tissue reserves/unit weight) or total carbohydrates per growing sink may be more important than the reserves per unit weight of tissue, although data on total pools are lacking. Priestley $(1960,1963,1970)$ and Hennerty and Forshey (1971) found that extractable reserves per unit weight of tissue were generally quite stable in response to stresses or manipulations, such as shading or defruiting, designed to affect carbon reserves. However, total tree growth (i.e., the "pool") responded directly to the treatments. Integrated studies of total carbon pools or fluxes concurrent with measurements of photosynthesis and respiration will be needed to elucidate the role of carbon reserves in the apple tree carbon balance.

\section{Leaf photosynthesis rate}

The light-saturated rate of photosynthesis per unit leaf area is commonly measured, and typically has been found to be $\approx 15-22$ $\mu \mathrm{mol} \cdot \mathrm{m}^{-2} \cdot \mathrm{s}^{-1}$ in apple (Flore and Lakso, 1989). These rates are moderate for $\mathrm{C}_{3}$ plants; they are higher than citrus and many tropicals, but lower than many annual crops such as wheat (Triticum aestivum L.) or soybean [Glycine $\max$ (L.) Merrill]. Consequently, an extremely high rate of photosynthesis per unit leaf area is not the primary reason for the high potential productivity of apple.

\section{Photosynthetic aging}

The photosynthetic rate of apple leaves is maximal shortly after full expansion, but declines only slowly over the season if the leaf remains healthy and fully exposed (Fujii and Kennedy, 1985; Porpiglia and Barden, 1980) (Fig. 1). The photosynthetic ability does decline, however, in the shade and shows little recovery upon re-exposure (Lakso et al., 1989; Porpiglia and Barden, 1980). The significance of the slow photosynthetic aging may be that the apple tree canopy can remain productive without continually producing young leaves over the entire season. This should lower respiratory costs of the canopy, since respiratory maintenance of mature leaves is lower than the high growth and maintenance respiration for new leaves (see Leaf Respiration section below).

\section{Leaf area development and duration}

A very important component of high productivity of apples relative to other crops is the long and adaptable leaf area duration. Since the tree is a perennial, the existing structure and the substantial carbon and nutrient reserves support very rapid canopy development in the spring (Palmer and Jackson, 1977; Fig. 2). The initial development is on short rosette-type shoots (commonly called "spurs") that develop leaf area very rapidly (Pratt, 1990). By bloom, $\approx 4$ weeks after budbreak, the canopy of a mature tree has developed $\approx 20 \%$ of its final leaf area (Forshey and Elfving, 1989; Palmer and Jackson, 1977; Wünsche et al., 1996). Leaf area development on the most vigorous extension shoots may continue until harvest, but canopy development typically terminates in midsummer. At the end of the season, the apple is adaptable to the climate, in that leaf senescence and abscission are controlled by temperature, not photoperiod (Jonkers, 1980; Lakso, Tustin and Corelli Grappadelli, unpublished data). Wünsche and Greer (unpublished data), using potted apple trees in controlledclimate rooms after fruit harvest, found that leaf abscission occurred within 2 weeks of exposure to $9{ }^{\circ} \mathrm{C}$ day $/ 4{ }^{\circ} \mathrm{C}$ night temperatures, whereas leaves exposed to $19{ }^{\circ} \mathrm{C}$ day/ $14{ }^{\circ} \mathrm{C}$ night temperatures remained photosynthetically active and did not senesce. This means

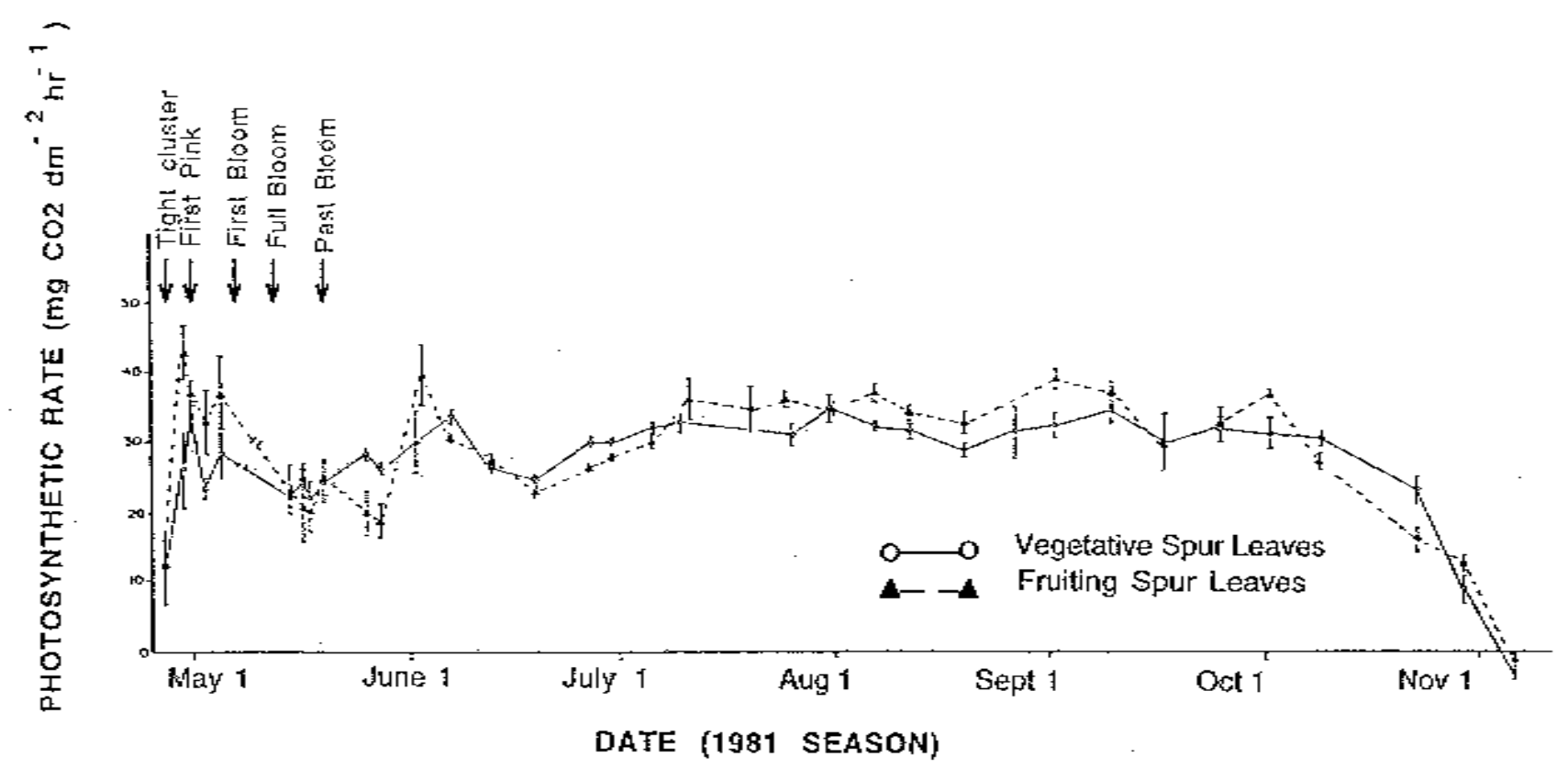

Fig. 1. Seasonal pattern of 'Delicious' apple spur leaf photosynthesis on excised branches from mature, cropping trees measured under standard laboratory conditions. Leaves from vegetative spurs and from fruiting spurs showed no consistent differences [from Fujii and Kennedy (1985), reproduced with permission from the American Society of Plant Physiologists]. 


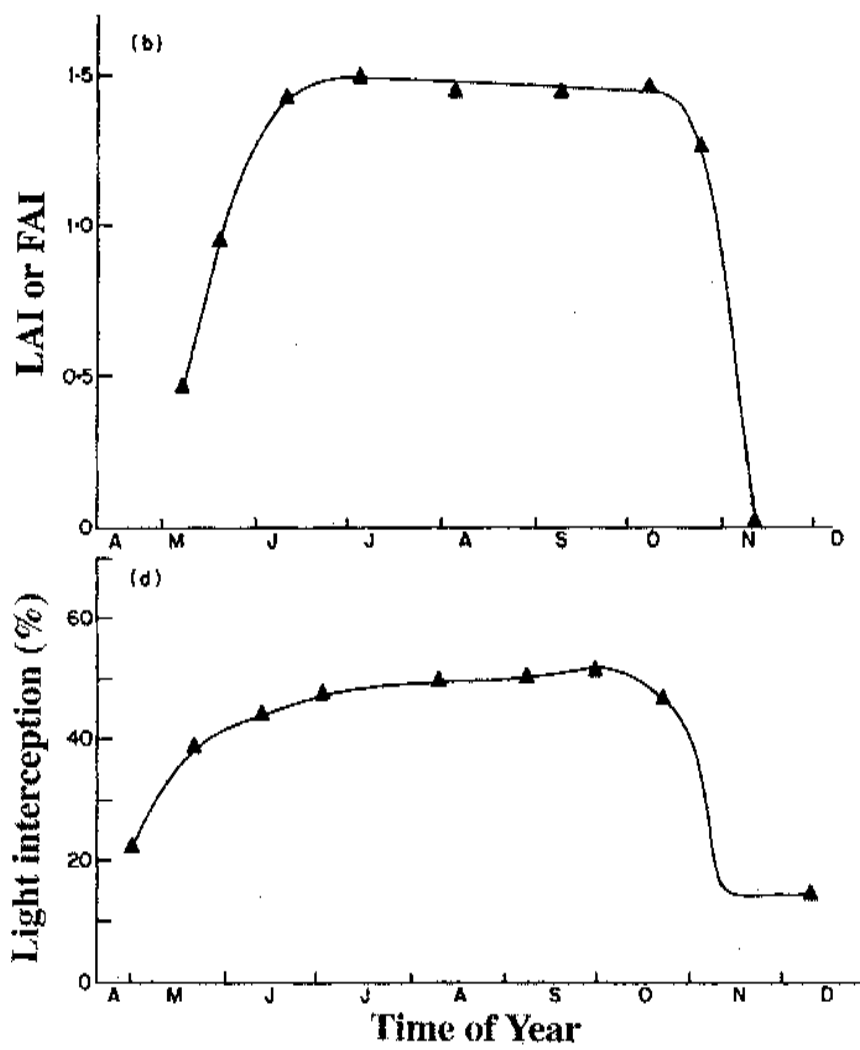

Fig. 2. (b) Seasonal leaf area index and (d) percent light interception of a 5-yearold 'Golden Delicious'/M.9 hedgerow planting at $0.9 \times 2.9$-m spacing [from Palmer and Jackson (1977), reproduced and edited with permission from Blackwell Scientific Publications].

that the apple tree canopy is maintained as long as the temperature allows, effectively adapting its leaf area duration to a wide range of climates.

\section{Seasonal light interception}

Given the need for alleyways between rows for spraying and harvesting, the maximum percent light interception of most apple orchards is typically $<70 \%$ of the available photosynthetic photon flux in midseason (Palmer and Jackson, 1977) (Fig. 2). Although the maximum interception is relatively low compared to field crops, the very long seasonal leaf area duration can allow quite high total seasonal light interception and dry-matter production. Efforts to increase light interception by ultrahigh planting densities of normal tree forms have generally failed, however, because of excessively dense canopies, poor fruit quality, and difficulties of management. An alternative approach that has been effective is extending the canopies over the alleyways with $\mathrm{V}$ - or $\mathrm{Y}$-shaped canopies to increase light interception and yields (Robinson and Lakso, 1991; Wünsche et al., 1996).

\section{Respiratory costs}

Respiration provides the energy for growth processes and for the maintenance of the tissue once formed (nutrient uptake, protein turnover, etc.). These respiratory costs are greatest for growth of new tissues (leaf, shoot, or root) and for tissue components that require high energy for synthesis (i.e., lipids, proteins, lignin) (Lakso and Denning, 1996). The fruit and other parts of the tree do not produce many energetically expensive compounds like oils or proteins, although lignin is produced in the wood. The lowest construction costs are for sugars, polysaccharides like starch, and for organic acids, all major components of apples. Thus, the apple tree should have relatively low respiration compared to many other crops because of low construction costs.

The most active growth and highest specific respiration rates (per weight of tissue) for apple occur in the spring when new leaves, shoots, fruits, stems, and roots grow most actively. Once leaf area development stops, and fruits complete cell division and commence cell expansion, the specific respiratory costs decline. The seasonal pattern of total respiration per tree, however, may be less variable as the amount of respiring tissue increases over the season while the specific respiration rate decreases. From data on total seasonal carbon budgets for a 4-year-old apple tree, the total dark respiratory loss as percentage of fixed $\mathrm{CO}_{2}$ was calculated by Wibbe et al. (1993) to be $27 \%$ for the growing season and $31 \%$ for a full year. Therefore, the dormant period did not appear to be a major component of yearly respiratory loss because of the long leaf area duration and low temperatures during dormancy. Wibbe et al. (1993) also found that fruiting increased total dark respiration, but the effect was much greater than the direct added effect of the fruit respiration alone. The fruit apparently stimulated both leaf photosynthesis and leaf respiration, and led to greater net carbon gain by $\approx 30 \%$.

Leaf respiration. Since mature leaves can function effectively for many months, the high growth costs of continually producing new leaves and stems are avoided, as seen in the seasonal leaf respiration data of Fujii and Kennedy (1985) (Fig. 3). The respiratory maintenance of a non-growing canopy of leaves appears to be relatively low, as mature leaf respiration rates are $\approx 5 \%$ to $10 \%$ of the photosynthetic rate at $25{ }^{\circ} \mathrm{C}$ (Amthor, 1989; Barden, 1977; Watson et al., 1978; unpublished data of the authors). In general, leaf respiration is certainly an important, if not dominant, component of canopy respiration due to the large leaf area and high respiration rates relative to fruits and stems.

Structural respiration. Since the main perennial aboveground structure of the tree is primarily dead stem tissue, maintenance costs are low (Butler and Landsberg, 1981). Interestingly, the respiration rates of stems of different ages are quite comparable if compared on a surface area basis (Butler and Landsberg, 1981; Lakso, unpublished data). This is probably due to the greatest respiration occurring in the cambium and phloem, sites of active growth and assimilate transport. Whole-tree prebloom measurements made in a gas exchange system showed a better relationship between dark respiration and wood surface than between dark respiration and wood volume in third-leaf apple trees (Codini et al., 1996). Separate measurements of the contribution of the perennial structure to the total respiration of the tree are difficult to obtain, but estimates by the dry-matter simulation model of Lakso and Johnson (1990), based on stem respiration rates and total tissue, suggest that, for a mature, slender spindle apple tree with a moderate crop, that the stem contributes $\approx 10 \%$ to $15 \%$ of the total respiration during the growing season (leaves $50 \%$ to $55 \%$, fruits $30 \%$ to $35 \%$ ). Overall, the respiration of the standing mass is probably relatively low for apple trees relative to annual plants.

Fruit gas exchange. The specific dark respiration rates of fruit are high during the early cell division period after bloom, then rapidly decline as growth by cell expansion begins (Bepete and Lakso, 1997; Jones, 1981). Since the fruit weight increases concurrently, the total respiration per fruit under nonlimiting conditions (an estimate of "demand") tends to reflect the seasonal curve of daily growth rate with an exponential increase for about a month, followed by a relatively stable rate for the rest of the season (Lakso et al., 1995, 1997) (Fig. 4). Since the skin of the fruit can photosynthetically refix respired $\mathrm{CO}_{2}$ (Blanke and Lenz, 1989), the net respiration rate can be reduced in the light to near-zero at full sunlight with a typical hyperbolic light response (Bepete and Lakso, 1997). Jones (1981) calculated that fruit photosynthetic re-fixation is only a small portion $(<15 \%)$ of the total seasonal carbon supply over the season, but it may be important to carbon economy of the fruit early in the season when there is intense competition for carbon. Shading of 'Empire' apple fruitlets during the cell division stage had little effect on growth but response was probably confounded by effects on fruit temperature (Lakso, unpublished data). For the season as a whole, fruit respiration of a normal crop appears to be a secondary component of the total tree respiration compared with the leaves (Blanke and Wibbe, 1991; Lakso, unpublished model estimates).

Root respiration. Root respiration and associated root growth and turnover are the least understood components of carbon balance. Heinicke and Childers (1937) measured respiration of young apple 


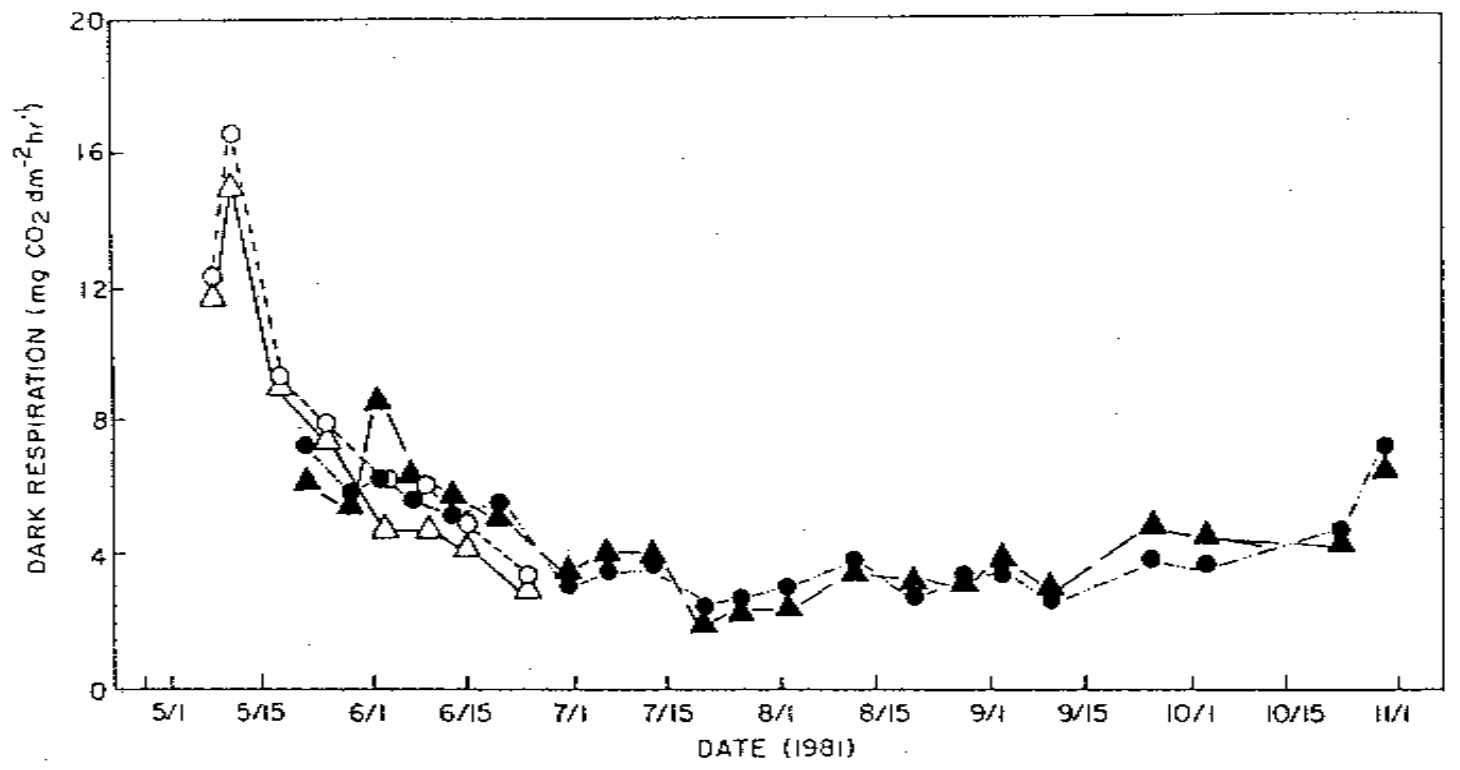

Fig. 3. Seasonal pattern of dark respiration of spur leaves of 'Delicious' apple on excised branches from mature, cropping trees measured under standard laboratory conditions. Leaves from vegetative spurs (circles) and from fruiting spurs (triangles) in 1981 (closed symbols) and 1982 (open symbols) showed no consistent differences [from Fujii and Kennedy (1985), reproduced with permission from the American Society of Plant Physiologists].

tree root systems after washing away the soil, and estimated $\mathrm{CO}_{2}$ evolution rates of $\approx 5-6 \mu \mathrm{mol} \cdot \mathrm{g}^{-1}$ at $20^{\circ} \mathrm{C}$. These are comparable to the rates of 7-9 $\mu \mathrm{mol} \cdot \mathrm{g}^{-1}$ reported by Ebert and Lenz (1991) and 5-20 $\mu \mathrm{mol} \cdot \mathrm{h}^{-1} \cdot \mathrm{g}^{-1}$ dry weight by Buwalda et al. (1992) for root systems in sand. These rates are relatively low compared with those of other plants (Amthor, 1989), but the size of the apple root system may be significant. Buwalda et al. (1992) found that root respiration rates decreased with top shading and low nitrogen supply, and they estimated that the apple root system may respire its own weight in carbon in $70-150 \mathrm{~d}$ at $20{ }^{\circ} \mathrm{C}$. Ebert and Lenz (1991) calculated that root respiration during September for 3-year-old apple trees was generally comparable with top respiration and was reduced by $50 \%$ by the presence of fruit. This represented $11 \%$ and $22 \%$ of the fixed $\mathrm{CO}_{2}$ in fruiting and nonfruiting trees. The reduced root respiration due to fruiting was probably due to the well-known reductions in root growth caused by cropping (Hansen, 1971; Lenz, 1986; Maggs, 1963; Palmer, 1992).

Observations summarized by Head (1973) and Atkinson (1985) and work in progress by D. Eissenstat and C. Wells (personal commu-

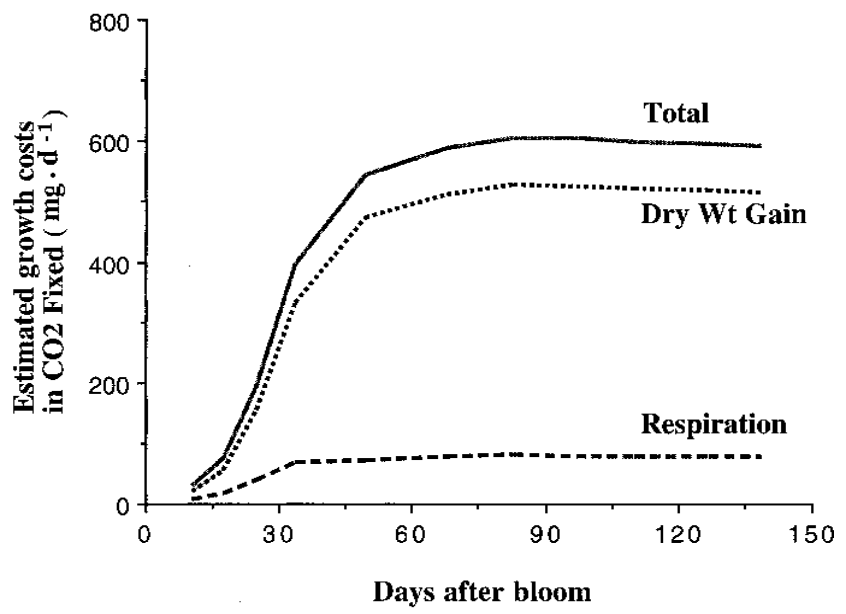

Fig. 4. Simulated seasonal fruit growth demand (respiration, dry-weight gain, and total) for fixed $\mathrm{CO}_{2}$ of 'Empire' apple fruits reaching $200 \mathrm{~g}$. The growth curve was "expolinear" as described by Lakso et al. (1995). Data generated from measurements and integrated by the model of Lakso and Johnson (1990). nication) indicate that apple root life spans of $\approx 3$ to 9 weeks are generally comparable with those of other fruit trees and annuals, but shorter than those of many slower-growing forest trees (Eissenstat and Yanai, 1997). Unfortunately, relatively few data have been published on root turnover in apple, so the carbon requirements of that potentially important component are unknown. Additionally, many different rootstocks are used in apple and their rates of root turnover are not known, suggesting that we must learn more about the dynamics and activities of root systems, and the differences among rootstocks.

\section{Harvest index}

Regardless of total dry-matter production, we are most interested in the amount partitioned to the fruit or organ of commerce. In this aspect, the potential of bearing apple orchards can be very high among crop species. Although the harvest index (fraction of total, or aboveground dry matter in fruit) may be zero or low in young or poorly managed orchards, bearing dwarf trees can have harvest indices from 0.50 to $\approx 0.80$ of the yearly dry matter produced, including root dry matter in some studies (Buwalda and Lenz, 1992; Forshey and McKee, 1970; Lakso, unpublished; Lenz, 1986; Palmer, 1988).

There are many possible reasons for these high values in a healthy, mature dwarf apple orchard. First, the investment in vegetative growth of the tree structure and dwarfing root systems is quite small, allowing greater partitioning to fruit. Second, the potential partitioning to fruit is indeterminate, since apple trees generally have a great excess of flowers that can be retained as fruits if conditions allow. Third, canopy management has improved, based on studies of light utilization and carbon partitioning that showed that exposure of the spur canopy is most important to carbon supply, growth, and set of fruits (Corelli Grappadelli et al., 1994; Ferree and Palmer, 1982; Hansen, 1967, 1969; Quinlan, 1965; Quinlan and Preston, 1971). Whole-orchard yields of differing systems have been found to be positively related to spur canopy light interception and negatively to extension shoot light interception (Wünsche et al., 1996). Thus, high fruit yields per hectare are possible from a combination of high harvest indices and high totalorchard dry-matter production resulting from good fertilization, pest protection, pruning and training, and orchard design.

\section{Effects of cropping on carbon balances and productivity}

Many investigators have studied the effects of cropping on the photosynthetic rate per unit leaf area and on dry-matter distribution in apple. Unfortunately, many early studies were limited by comparing 
only no crop with one level of cropping to examine relationships that have been found to be curvilinear. Although a comprehensive review of this complex and important effect is not possible here, some general conclusions can be proposed.

The photosynthetic rate per unit leaf area typically is low with zero or very low crop loads, especially in the mid- to late season after alternate vegetative sinks have terminated growth. Increases in crop load increase leaf photosynthesis rates, but little increase is seen above moderately low crop loads (Giuliani et al., 1998; Palmer, 1992; Palmer et al., 1997). Very low or zero crop loads appear to down-regulate leaf photosynthesis rates, as indicated by the high leaf dry-weight densities found at such crop loads (Giuliani et al., 1998; Palmer et al., 1997). Changes in crop load from moderately low to very high have little effect on leaf photosynthesis rates; this may be interpreted as a "normal" rate of photosynthesis that occurs with adequate sink demand and cannot be stimulated.

Whole-plant effects are more complex. The effect of cropping on leaf area development tends to be quite variable, with some studies reporting marked increases in leaf area per tree with low or zero crop load (Avery, 1969; Giuliani et al., 1998; Lenz, 1986; Maggs, 1963; Wünsche and Palmer, 1998), while others report little effect (Palmer, 1992; Palmer et al., 1997; Wibbe et al., 1993). As crop load increases, increasing photosynthesis rate per unit leaf area may be compensated for by decreasing leaf area per tree, leading to similar whole-canopy net $\mathrm{CO}_{2}$ uptake per tree on trees of differing crop loads (Ebert and Lenz, 1991; Giuliani et al., 1998; Wünsche and Palmer., 1998). Long-term growth analyses, however, indicate that cropping generally significantly increases total dry-matter gain (Avery, 1969; Lenz, 1986; Maggs, 1963; Palmer, 1988). As the fruit dry-matter fraction increases, the root growth component is generally reduced the most, while shoot growth and leaf areas decline less (Hansen, 1971; Lenz, 1986; Palmer, 1992). Lenz (1986) found that 2 years of cropping in $3-$ year-old trees reduced vegetative growth so much that the total drymatter production was lower than for trees cropping only in the third year. This suggests that too much fruit can depress the productivity of the whole tree. In contrast, Wibbe et al. (1993) found that a young cropping apple tree had almost twice the daily canopy net $\mathrm{CO}_{2}$ uptake and total carbon production of a de-fruited tree, while cropping had little apparent effect on leaf area per tree.

The relative importance of changes in leaf photosynthesis rate vs. leaf area, however, appears to vary with tree age, canopy density, and perhaps other stresses. In open orchards, especially with young trees, light interception per tree tends to be well correlated with tree leaf area; thus, changes in leaf area should be important. In more mature orchards and denser canopies, changes in leaf area may have little effect on tree light interception, so leaf photosynthesis rates may be the primary regulator of variations in canopy net $\mathrm{CO}_{2}$ uptake per tree. In addition to affecting photosynthesis, cropping may also affect respiration rates of different organs. Wibbe et al. (1993) found that cropping increased dark canopy respiration primarily via increased leaf respiration, presumably related to increased metabolic activity. As mentioned earlier, Ebert and Lenz (1991) found that fruiting decreased root respiration, probably because of the reduction of root growth.

\section{INTEGRATIVE APPROACHES}

\section{Growth analysis}

To obtain integrated carbon production and utilization values, several approaches can be used. Growth analysis is extremely useful, as it provides actual integrals of increases in dry matter (Forshey and McKee, 1970; Forshey et al., 1983; Hansen, 1971; Lenz, 1986; Maggs, 1960, 1963; Palmer, 1988; Proctor et al., 1976). However, with mature apple trees in the field it is difficult to determine starting dry weights, to examine short term trends or responses to weather, and to separate the components of the dry-matter accumulation (i.e., photosynthesis and respiration).

\section{Gas exchange measurements}

The measurement of the gas exchange of plant parts such as leaves or fruits has allowed shorter-term measurements of carbon balance components. Leaf photosynthesis and respiration measurements are relatively easy to do with modern equipment, even in the field. However, scaling up from the leaf to the whole canopy is not straightforward because of variable within-canopy microclimates, variations in leaf age and function, and the complexity of radiation geometry in discontinuous canopies. Although computer models have been developed to do this scaling (see section on Modeling), several researchers have chosen to measure whole-canopy gas exchange directly.

The first, and still most complete, study was the 180-d continuous measurement of canopy gas exchange of a single 8-year-old apple tree in 1935 by A.J. Heinicke and N. Childers (Heinicke and Childers, 1937). (Dr. Childers is still active and attended the meeting at which this paper was given, over 60 years later!) Daily net $\mathrm{CO}_{2}$ exchange became positive at about full bloom, approached a maximum $\approx 4-6$ weeks after bloom with full canopy development, maintained a fairly stable

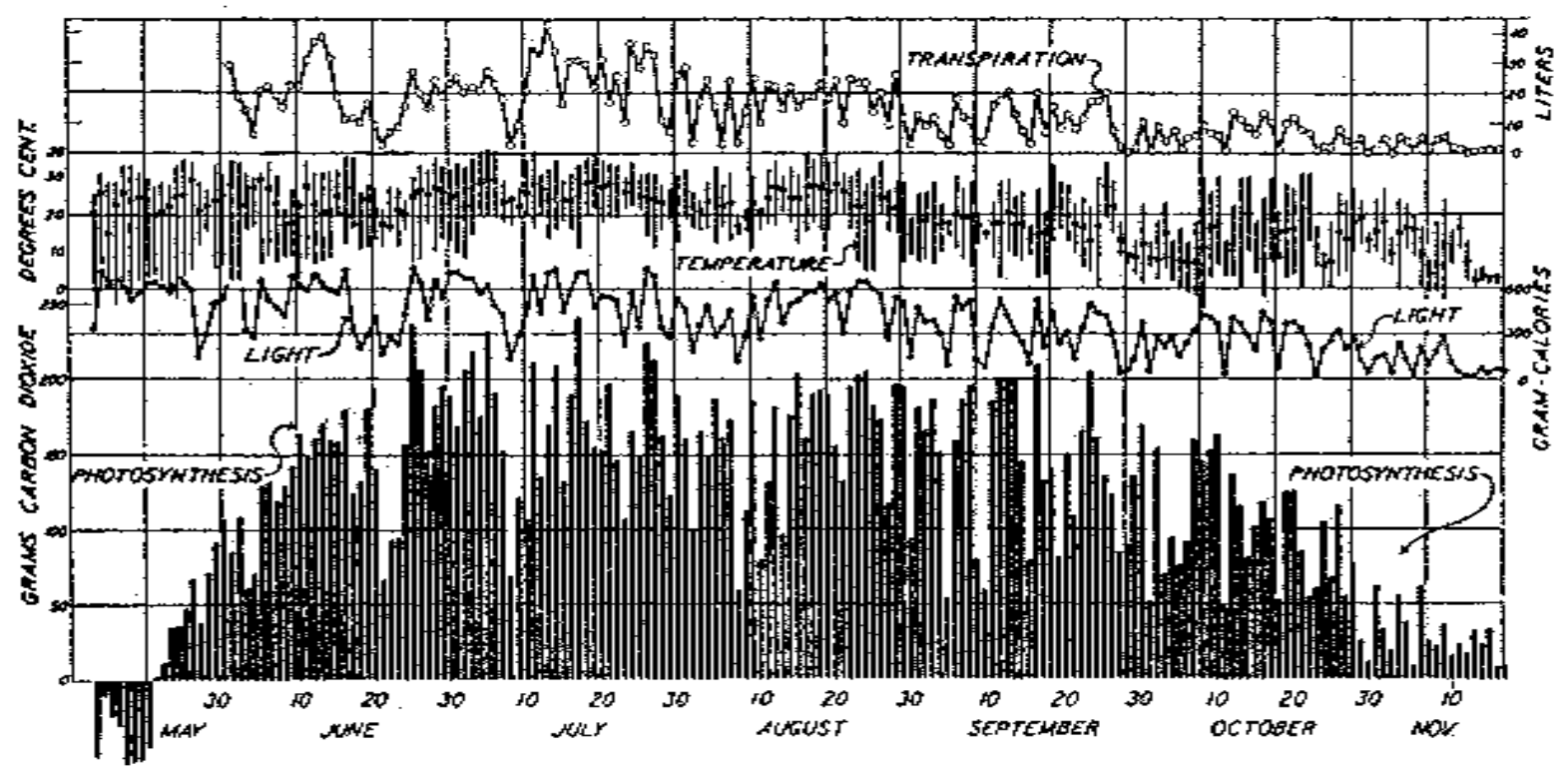

Fig. 5. Seasonal pattern of daily net $\mathrm{CO}_{2}$ uptake of an 8-year-old 'McIntosh' apple tree canopy enclosed in a glass chamber in 1935 [reproduced from Heinicke and Childers (1937)]. 


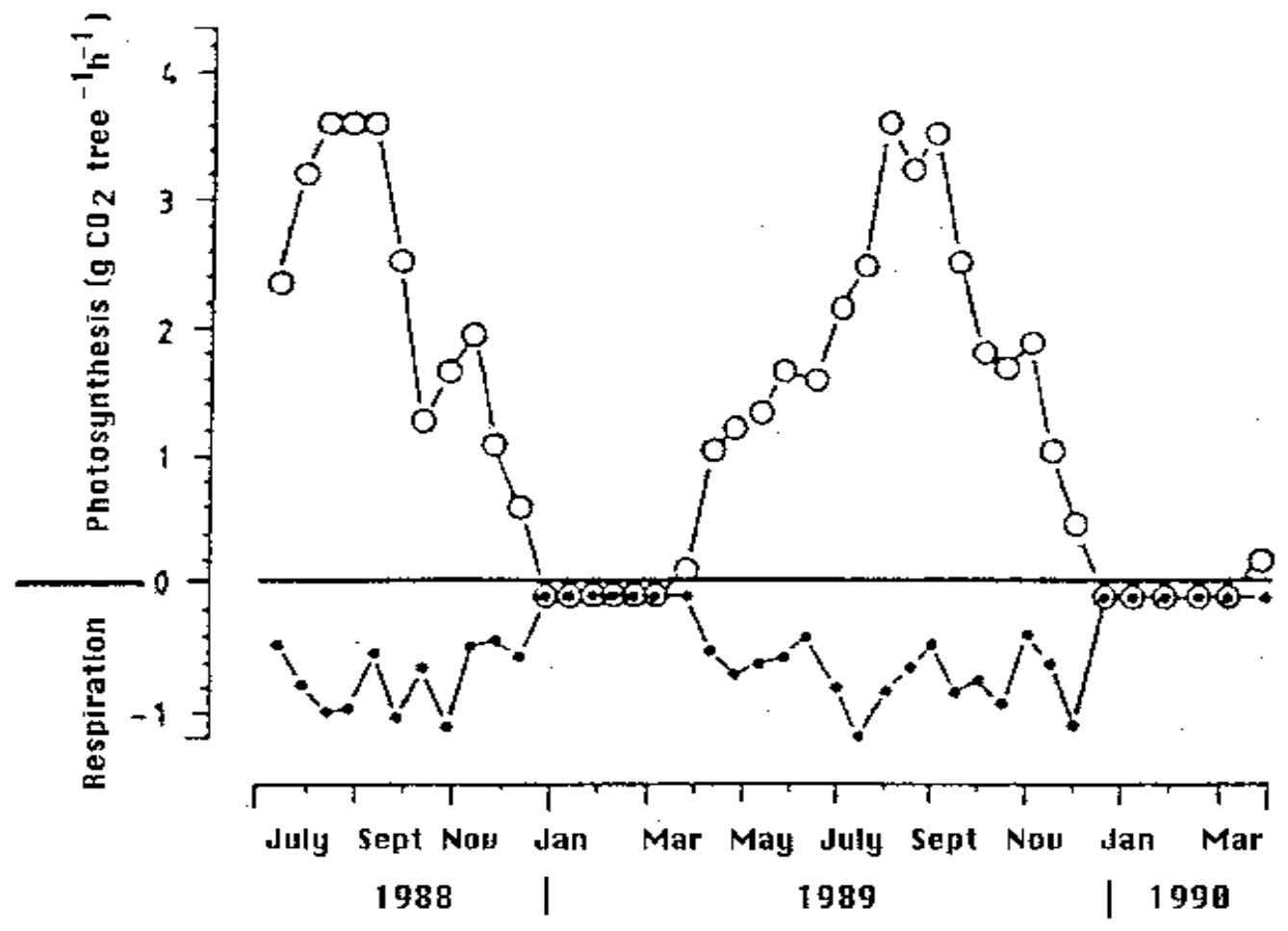

Fig. 6. Seasonal patterns of whole canopy net $\mathrm{CO}_{2}$ exchange in the light (open symbols) and dark (closed symbols) periods during the third and fourth year of a 'Golden Delicious'/M9 apple tree [from Wibbe et al. (1993), reproduced with permission from Springer-Verlag GmbH and Co.].

rate for $\approx 10$ weeks, then declined to zero as leaves abscised (Fig. 5).

More recently, whole canopy carbon exchange has been estimated with lighter weight and more flexible cuvette systems, using modern infrared gas analysis and sometimes automated data logging (Corelli Grappadelli and Magnanini, 1993; Lakso et al., 1996; Proctor et al., 1976; Sirois and Cooper, 1964; Wibbe et al., 1993, 1994; Wünsche and Palmer, 1997). Wibbe et al. (1993) monitored year-round light and dark period $\mathrm{CO}_{2}$ exchange of a young apple tree in its third and fourth season (Fig. 6). In this case, the seasonal curve showed much sharper peaks of photosynthesis in midseason. The reasons for the difference between the seasonal patterns of Wibbe et al. and Heinicke and Childers are not clear, but may be due to seasonal climatic differences, variation in canopy development (leaf area development in young trees is more gradual), or equipment differences in temperature control and light transmission. Whole-canopy gas exchange appears to be a valuable technique for continuing studies of carbon balance of apples in the field.

\section{MODELING CARBON SUPPLY/DEMAND BALANCES}

Efforts have been made to model apple tree photosynthesis and carbon balance (Elfving et al., 1983; Landsberg, 1979; Seem et al., 1986; Thorpe et al., 1978) and are currently in progress (Wagenmakers, 1996). For example, a simplified whole-tree carbon balance/drymatter production model (Lakso and Johnson, 1990) was used to estimate general seasonal curves of canopy net $\mathrm{CO}_{2}$ fixation per day (daily leaf photosynthesis minus respiration of fruit, leaves, and wood) using long-term weather records from Geneva, N.Y. General seasonal demands of individual fruits were estimated from seasonal curves of dry-matter gain, dark respiration rates, and bioenergetic construction costs (Lakso and Denning, 1996; Lakso et al., 1998).

Comparison of simulated carbohydrate supply and demand curves for an apple tree suggest several important points (Fig. 7). First, the supply and demand curves have different shapes, indicating that there are periods when the carbon supply for fruit development is limiting or is excessive. Neither is desirable, but, for commercially acceptable fruit size and long-term cropping, having too much carbon is better than having too little. Growth processes of the canopy and roots require an adequate carbon supply to maintain long-term tree health and productivity. There are two periods when the probability is highest of fruit production being limited by the carbohydrate supply, and the probability increases with increasing crop load.

The first period is $\approx 2-4$ weeks after full bloom, when the carbohydrate demand of the crop increases rapidly because of many fruits and their exponential growth rate. At this time, competition between fruit and shoot development for the carbon supply reduces the fraction available to the fruit, especially if the incident light is low (Bepete and Lakso, 1998). For example, dry-matter growth for shoots is $\approx 200-300$

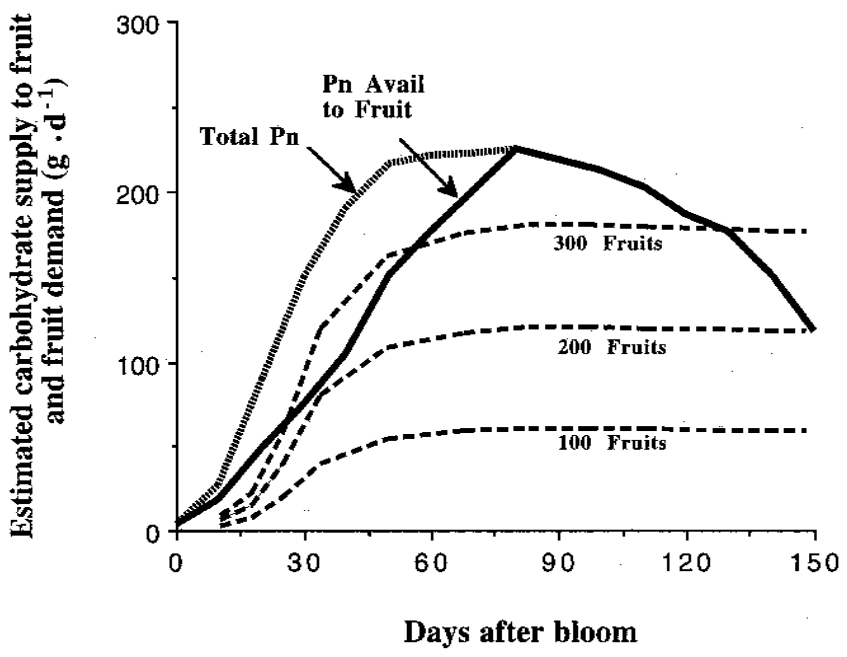

Fig. 7. Model simulations of seasonal total canopy photosynthesis of a healthy, mature slender spindle dwarf apple tree $\left(\approx 15 \mathrm{~m}^{2}\right.$ leaf area; orchard Leaf Area Index $=3$ ) bearing 100 , 200, or 300 fruits that have 200 -g final potential weight. Simulations run with a modified model of Lakso and Johnson (Lakso and Johnson, 1990) and 10-year mean weather data for Geneva, N.Y. Total canopy photosynthesis and the estimated amount potentially available to the fruit are shown to indicate competition for carbon during the early season. 
$\mathrm{mg} \cdot \mathrm{d}^{-1}$ (Bepete and Lakso, 1998; Lakso, unpublished data) at daily mean temperatures of 15 to $18{ }^{\circ} \mathrm{C}$. For a slender spindle tree as modeled, 200 actively growing shoots at 3 weeks after bloom would require $\approx 40-60 \mathrm{~g}$ of dry matter (and about twice that amount in fixed $\mathrm{CO}_{2}$ ), a value greater than one-half of the total fixation by the canopy at that time. The total carbon available to the fruit then was reduced in the simulation (Fig. 7) to reflect competition from actively growing shoots during the early season. Of course, the relative amount of shoot competition will depend on tree vigor, which is affected by cultivar, nutrition, water status, and pruning.

The second period may occur late in the season, during final fruit sizing before harvest, because of declining incident light and cooler temperatures. We have observed (unpublished data) that fruit growth rates can remain linear until harvest on lightly cropped trees, but decline on heavily cropped trees late in the season, again indicating interactions with crop load. This late-season effect may be aggravated by pest effects, such as late-season injury by European red mite [Panonychus ulmi (Koch)] (Francesconi et al., 1996; Marini et al., 1994), especially in cooler seasons when ripening is delayed. In longer seasons, this late-season effect may be reduced if the ripening occurs during warmer sunnier weather in late summer.

\section{Non-carbon limitations}

Although this discussion has centered on carbon, carbon will not always be the limiting and, thus, regulating factor in tree performance. As the carbon balance changes and growth increases or decreases, nutrients, water, or environmental factors may become limiting. For example, the senior author has observed that vegetative growth in an orchard with a mild deficiency of magnesium was strongly reduced as crop load increased. After correcting the magnesium deficiency, the same orchard showed much less effect of crop load on vegetative growth, probably a truer picture of competition for carbon. We need to consider all these aspects as increases in atmospheric carbon dioxide continue. The value of results of carbon balance studies will be greater, however, if they are combined with other approaches, such as growth analysis or computer modeling, while also monitoring the status of other potentially limiting factors, such as mineral nutrients or water status.

In summary, the apple tree has an inherent potential for high dry matter and fruit productivity due to its ability to intercept a high amount of radiation over a long period with efficient, long-lived leaves, to produce organs with relatively low construction costs and maintenance, thus giving low respiratory costs, and to partition a high percentage of its dry matter into fruit. Estimation of seasonal dry matter and gas exchange via computer modeling indicates that there may be two periods of greatest probability for carbon limitation to fruit development. The challenge to physiological research is to not only understand these bases of productivity, but also to learn how to regulate them for optimal orchard productivity and fruit quality.

\section{Literature Cited}

Amthor, J.S. 1989. Respiration and crop productivity. Springer-Verlag, New York.

Atkinson, D. 1985. Spatial and temporal aspects of root distribution as indicated by the use of a root observation laboratory, p. 43-65. In: A.H. Fitter, D. Atkinson, D J. Read, and M.B. Usher (eds.). Ecological interactions in soil. Plants, microbes and animals. Blackwell Scientific, Oxford, U.K.

Avery, D.J. 1969. Comparisons of fruiting and deblossomed maiden apple trees, and of non-fruiting trees on a dwarfing and an invigorating rootstock. New Phytol. 68:323-336.

Barden, J.A. 1977. Apple tree growth, net photosynthesis, dark respiration, and specific leaf weight as affected by continuous and intermittent shade. J. Amer. Soc. Hort. Sci 102:391-394.

Bepete, M. and A.N. Lakso. 1997. Apple fruit respiration in the field: Relationships to fruit growth rate, temperature, and light exposure. Acta Hort. 451:319-326.

Bepete, M. and A.N. Lakso. 1998. Differential effects of shade on early season fruit and shoot growth rates in 'Empire' apple branches. HortScience 33:823-825.

Blanke, M.M. and F. Lenz. 1989. Fruit photosynthesis. Plant Cell Environ. 12:31-46.
Blanke, M.M. and M. Wibbe. 1991. Contribution of fruit respiration to the carbon balance of an apple tree in the vegetation period. Gartenbauwissenschaft 56:138-139.

Butler, D.R. and J.J. Landsberg. 1981. Respiration rates of apple trees, estimated by $\mathrm{CO}_{2}$-efflux measurements. Plant Cell Environ. 4:153-159.

Buwalda, J.G., M. Fossen, and F. Lenz. 1992. Carbon dioxide efflux from roots of calamo[n]din and apple. Tree Physiol. 10:391-401.

Buwalda, J.G. and F. Lenz. 1992. Effects of cropping nutrition and water supply on accumulation and distribution of biomass and nutrients for apple trees on M9 root systems. Physiol. Plant. 84:21-28.

Codini, M., L. Corelli-Grappadelli, and E. Magnanini. 1996. Sistema chiuso per la misura della respirazione in alberi di melo in vaso, p. 129-130. In: G. Barbera, E. Barone, and F. Sottile (eds.). Proc. 'III Giornate SOI'. Soc. Ortoflorofrutt. Ital., Bologna, Italy.

Corelli Grappadelli, L., A.N. Lakso, and J.A. Flore. 1994. Early season patterns of carbohydrate partitioning in exposed and shaded apple branches. J. Amer. Soc. Hort. Sci. 119:596-603.

Corelli Grappadelli, L. and E. Magnanini. 1993. A whole tree system for gas exchange studies. HortScience 28:41-45.

Ebert, G. and F. Lenz. 1991. Jahresverlauf der Wurzelatmung von Apfelbäumen und ihr Beitrag zur $\mathrm{CO}_{2}$-Bilanz. Gartenbauwissenschaft 56:130-133.

Eissenstat, D. and R. Yanai. 1997. The ecology of root lifespan. Adv. Ecol. Res. 27:1-60.

Elfving, D.C., S.M. Welch, and G.P. Kroh. 1983. Apple tree modeling and IPM, p. 271-307. In: B.A. Croft and S.C. Hoyt (eds.). Integrated pest management of insect pests of pome and stone fruits. Wiley, New York.

Ferree, D.C. and J.W. Palmer. 1982. Effect of spur defoliation and ringing during bloom on fruiting, fruit mineral level, and net photosynthesis of 'Golden Delicious' apple. J. Amer. Soc. Hort. Sci. 107:1182-1186.

Flore, J.A. and A.N. Lakso. 1989. Environmental and physiological regulation of photosynthesis in fruit crops. Hort. Rev. 11:111-157.

Forshey, C.G. and D.C. Elfving. 1989. The relationship between vegetative growth and fruiting in apple trees. Hort. Rev. 11:229-287.

Forshey, C.G. and M.W. McKee. 1970. Production efficiency of a large and a small 'McIntosh' apple tree. HortScience 5:164-165.

Forshey, C.G., R.W. Weires, B.H. Stanley, and R.C. Seem. 1983. Dry weight partitioning of 'McIntosh' apple. J. Amer. Soc. Hort. Sci 108:149-154.

Francesconi, A.H.D., A.N. Lakso, J.P. Nyrop, J. Barnard, and S.S. Denning. 1996. Carbon balance as a physiological basis for the interactions of European red mite and crop load on 'Starkrimson Delicious' apple trees. J. Amer. Soc. Hort. Sci 121:959-966.

Fujii, J.A. and R.A. Kennedy. 1985. Seasonal changes in the photosynthetic rate in apple trees. A comparison between fruiting and nonfruiting trees. Plant Physiol. 78:519-524.

Giuliani, R., L. Corelli-Grappadelli, and E. Magnanini. 1998. Effects of crop load on apple photosynthetic responses and yield. Acta Hort. 451:303-311.

Hansen, P. 1967. ${ }^{14} \mathrm{C}$-studies on apple trees. II. Distribution of photosynthates from top and base leaves from extension shoots. Physiol. Plant. 20:720725.

Hansen, P. 1969. ${ }^{14} \mathrm{C}$-studies on apple trees. IV. Photosynthate consumption in fruits in relation to the leaf-fruit ratio and to the leaf-fruit position. Physiol. Plant. 22:186-198.

Hansen, P. 1971. The effect of cropping on the distribution of growth in apple trees. Tidsskrift Planteavl 75:119-127.

Head, G.C. 1973. Shedding of roots, p. 237-293. In: T.T. Kozlowski (ed.). Shedding of plant parts. Academic, New York.

Heinicke, A.J. and N.F. Childers. 1937. The daily rate of photosynthesis, during the growing season of 1935, of a young apple tree of bearing age. Cornell Univ. Agr. Expt. Sta. Memoir 201

Hennerty, M.J. and C.G. Forshey. 1971. Effects of defruiting, scoring, defoliation and shading on the carbohydrate content of 'Golden Delicious' apple trees. J. Hort. Sci. 46:153-161.

Jackson, J.E. 1980. Light interception and utilization by orchard systems. Hort. Rev. 2:208-267.

Jones, H.G. 1981. Carbon dioxide exchange of developing apple (Malus pumila Mill.) fruits. J. Expt. Bot. 32:1203-1210.

Jonkers, H. 1980. Autumnal leaf abscission in apple and pear. Fruit Sci. Rpt. 7:25-29.

Lakso, A.N. 1994. Apple, p. 3-42. In: B. Schaffer and P.C. Andersen (eds.). Environmental physiology of fruit crops. Vol. I. Temperate fruits. CRC Press, Boca Raton, Fla.

Lakso, A.N., M. Bepete, M.C. Goffinet, and L.C. Corelli Grappadelli. 1998. Aspects of carbon supply and demand in apple fruits. Acta Hort. 466:1318.

Lakso, A.N., L. Corelli Grappadelli, J. Barnard, and M.C. Goffinet. 1995. An expolinear model of the growth pattern of the apple fruit. J. Hort. Sci 70:389-394.

Lakso, A.N. and S.S. Denning. 1996. Seasonal bioenergetic construction costs of apple fruits, leaves and shoots. Acta Hort. 416:163-168. 
Lakso, A.N. and R.S. Johnson. 1990. A simplified dry matter production model for apple using automatic programming simulation software. Acta Hort. 276:141-148.

Lakso, A.N., G.B. Mattii, J.P. Nyrop, and S.S. Denning. 1996. Influence of European red mite on leaf and whole canopy $\mathrm{CO}_{2}$ exchange, yield, fruit size, quality and return cropping in 'Delicious' apple trees. J. Amer. Soc. Hort. Sci 121:954-958.

Lakso, A.N., T.L. Robinson, and S.G. Carpenter. 1989. The palmette leader, a tree design for improved light distribution. HortScience 24:271-275.

Landsberg, J.J. 1979. Effects of weather on apple productivity. Rpt. Long Ashton Res. Sta. for 1978, p. 196-212.

Lenz, F. 1986. Fruit effects on transpiration and dry matter production in apples, p. 101-104. In: A. Lakso and F. Lenz (eds.). Regulation of photosynthesis in fruit trees. New York State Agr. Expt. Sta. Spec. Publ., Geneva.

Maggs, D.H. 1960. The stability of the growth pattern of young apple trees under four levels of illumination. J. Hort. Sci. 24:434-450.

Maggs, D.H. 1963. The reduction in growth of apple trees brought about by fruiting. J. Hort. Sci. 38:119-128.

Marini, R.P., D.G. Pfeiffer, and D.S. Sowers. 1994. Influence of European red mite (Acari:Tetranychidae) and crop density on fruit size and quality and on crop value of 'Delicious' apples. J. Econ. Entomol. 87:1302-1311.

Minchin, P.E.H., M.R. Thorpe, J.N. Wunsche, J.W. Palmer, and R.F. Picton. 1997. Carbon partitioning between apple fruits: Short- and long-term response to availability of photosynthate. J. Expt. Bot. 48:1401-1406.

Monteith, J.L. 1977. Climate and the efficiency of crop production in Britain. Phil. Trans. Royal Soc. London B 281:277-294.

Palmer, J.W. 1988. Annual dry matter production and partitioning over the first 5 years of a bed system of Crispin-M.27 apple trees at four spacings. J. Appl. Ecol. 25:569-578.

Palmer, J.W. 1989. Canopy manipulation for optimum utilisation of light, p. 245-262. In: C.J. Wright (ed.). Manipulation of fruiting. Butterworths, London.

Palmer, J.W. 1992. Effects of varying crop load on photosynthesis, dry matter production and partitioning of Crispin/M.27 apple trees. Tree Physiol. 11:19-33.

Palmer, J.W., R. Giuliani, and H.M. Adams. 1997. Effect of crop load on fruiting and leaf photosynthesis of 'Braeburn'/M.26 apple trees. Tree Physiol. 17:741-746.

Palmer, J.W. and J.E. Jackson. 1977. Seasonal light interception and canopy development in hedgerow and bed system apple orchards. J. Appl. Ecol. 14:539-549.

Porpiglia, P.J. and J.A. Barden. 1980. Seasonal trends in net photosynthetic potential, dark respiration, and specific leaf weight of apple leaves as affected by canopy position. J. Amer. Soc. Hort. Sci. 105:920-923.

Pratt, C.S. 1990. Apple trees: Morphology and anatomy. Hort. Rev. 12:265305.

Priestley, C.A. 1960. Seasonal changes in the carbohydrate resources of some six-year-old apple trees. Rpt. East Malling Res. Sta. for 1959, p. 70-77.

Priestley, C.A. 1963. The carbohydrate resources of young apple trees under four levels of illumination. Ann. Bot. 27:435-446.

Priestley, C.A. 1970. Carbon storage and utilization, p. 113-127. In: L.C. Luckwill and C.V. Cutting (eds.). Physiology of tree crops. Academic, London.

Proctor, J.T.A., R.L. Watson, and J.J. Landsberg. 1976. The carbon balance of a young apple tree. J. Amer. Soc. Hort. Sci. 101:579-582.

Quinlan, J.D. 1965. The pattern of distribution of ${ }^{14}$ carbon in a potted apple rootstock following assimilation of ${ }^{14}$ carbon dioxide by a single leaf. Rpt. East Malling Res. Sta. for 1964, p. 117-121.

Quinlan, J.D. and A.P. Preston. 1971. The influence of shoot competition on fruit retention and cropping of apple trees. J. Hort. Sci. 46:525-534.

Robinson, T.L. and A.N. Lakso. 1991. Bases of yield and production efficiency in apple orchard systems. J. Amer. Soc. Hort. Sci. 116:188-194.

Russell, G., P.G. Jarvis, and J.L. Monteith. 1989. Absorption of radiation by canopies and stand growth, p. 21-39. In: G. Russell, B. Marshall, and P.G. Jarvis (eds.). Plant canopies: Their growth, form and function. Cambridge Univ. Press, Cambridge, U.K.

Seem, R.C., D.C. Elfving, T.R. Oren, and S.P. Eisensmith. 1986. A carbon balance model for apple tree growth and production. Acta Hort. 184:129_ 137.

Sirois, D.J. and G.R. Cooper. 1964. The influence of light intensity, temperature and atmospheric carbon dioxide concentration on the rate of apparent photosynthesis of a mature apple tree. Maine Agr. Expt. Sta. Bul. 626.

Thorpe, M.R., B. Saugier, S. Auger, A. Berger, and M. Methy. 1978. Photosynthesis and transpiration of an isolated tree: Model and validation. Plant Cell Environ. 1:269-277.

Wagenmakers, P.S. 1991. Planting systems for fruit trees in temperate climates. Crit. Rev. Plant Sci. 10:369-385.

Wagenmakers, P.S. 1996. Effects of light and temperature on potential apple production. Acta Hort. 416:191-197.

Watson, R.L., J.J. Landsberg, and M.R. Thorpe. 1978. Photosynthetic characteristics of the leaves of 'Golden Delicious' apple trees. Plant Cell Environ. 1:51-58.

Wibbe, M.L., M.M. Blanke, and F. Lenz. 1993. Effect of fruiting on carbon budgets of apple tree canopies. Trees 8:56-60.

Wibbe, M.L., M.M. Blanke, and F. Lenz. 1994. Net photosynthesis, dark respiration and $\mathrm{CO}_{2}$ balance of apple trees. Gartenbauwissenschaft 59:3439.

Wünsche, J.N., A.N. Lakso, T.L. Robinson, F. Lenz, and S.S. Denning. 1996. The bases of productivity in apple production systems: The role of light interception by different shoot types. J. Amer. Soc. Hort. Sci. 121:886-893.

Wünsche, J.N. and J.W. Palmer. 1997. Portable through-flow cuvette system for measuring whole-canopy gas exchange of apple trees in the field. HortScience 32:653-658.

Wünsche, J.N. and J.W. Palmer. 1998. Effects of fruiting on seasonal leaf and whole-canopy carbon dioxide exchange of apple. Acta Hort. 451:295-301. 